\title{
They falsified my name
}

\author{
Arnold Mampioper
}

The Indonesian forces had entered Etna Bay! Their commander was a Lieutenant Mampioper! I was very surprised to hear this news. All eyes looked suspiciously in my direction. How could it be that the name was precisely the same as my own - I, Arnold Mampioper, none other than the district head of Etna, a member of the staff of the resident of West Nieuw-Guinea (the Dutch government).

The HPB of Kaimana, F.H. Peters, who was my boss, immediately asked: 'Do you have a brother who is in the Indonesian army?' Oh no, I did not. There was someone from my village, a cousin of mine, who was in North Maluku, but he was not in the military. I was not sure about that name. It could well be a ploy to engage people in helping the Indonesian military commander because his fam (family or kin) were the same as the head of their district's. But it remained to be seen whether he was really Mampioper, or the name was just a pseudonym.

It was April 1955. I was taking part in a patrol group with the HPB of Kaimana, F.H. Peters, the aspiran controleur (incoming prospective controller) of Fakfak, F. Veldkamp, the district medical doctor of Fakfak, Dr. Vink, the paramedic, Ubara, the chief of police, Van Krieken, and second-class veldwachter (village policeman), Sarara. We were patrolling Titinama (Maramani) and surrounding areas, such as the villages of Jereijepa, Debaka, Keghete, Odiburai, Moanemani, Waigeta and Enarotali. I heard the news when our patrol group was about to return to Etna Bay. The additional information we got was that Lieutenant Mampioper's forces had divided in two. A large group was proceeding to Lake Jamor. Meanwhile, Commander Mampioper and one platoon were coming up to meet us or intercept us at kampung Maramani (Titinima).

The problem of the similarity of the name was, for the time being, not the first thing to be considered. We were more concerned about how 
to walk home without running into the Indonesian troops. Doctor Vink recommended going through Lake Jamor. Mr. F. Veldkamp suggested we return to Enarotali. Whereas HPB Peters suggested going down following the Aindua river on the west coast by the Kaimana-Mimika border.

I responded. If we went to Lake Jamor, the Republic of Indonesia (RI) troops were heading there. Returning to Enarotali would be tough since we had no food. There were the sweet potato crops of the inhabitants, but could the gentlemen survive on these? Following the Aindua was good, but the river did not flow swiftly all the way to the coast. As a result we might get to the middle but be unable go further with a raft, floating and constrained by the sea tides. We might run out of food and drink and be attacked by mosquitoes. We could not be sure of meeting anyone to help us.

I proposed that we follow the road we were already travelling. The commander of the RI troops would not block us, for fear that the police in the HPB patrol would demolish them. I thought that they were coming to find us there, but that the villagers would take them walking on the mountainside, so as to avoid meeting us. I was the one who walked in the front. We did not follow the existing road, but walked three or four metres to the side of the trail so we could keep watch on whether or not the way before us was safe. So they could see the signs I placed on the path which meant it was safe and they could keep going.

In the lowlands it was more difficult because we could not see very far ahead. Because of that I walked far ahead to see if the enemy was blocking us. If there was anything dangerous, I would shoot as a signal in their direction for them to cross the river. There was a small village there, Isadiso, where we could get help with food and seek information. But I was sure there would be a police or army patrol to safeguard our arrival. Finally, we encountered what I had predicted. A group of young policemen showed up, deftly coming to pick us up and lead us safely to the marine and police patrol post in Napuri on the bank of the Omba river.

Upon receiving the report on the Indonesian troops, the resident of Fakfak, F.R.J. Eibrink Jansen departed on the KM Maro (the patrol boat of the resident of Fakfak), and entered Lake Janor with a mobile brigade to inspect the marine and police patrol that had come to pursue the Indonesian troops under the command of Lieutenant Mampioper. It turned out that the name was false. His true name was Lieutenant D.J. 
Dimara. His mission was to persuade the people of Papua to drive the Dutch out of West Papua.

When the resident returned from Lake Jamor, he received our delegation but he would not receive me. In his speech, he said: 'Now I won't shake your hand, you are our enemy. Only once it has been proven that you are not guilty can you be a friend again.' I replied to him: 'Very well, Your Excellency, all I know is to work for the people of Papua, who have been abandoned by Holland and Indonesia for centuries, who I am struggling to develop, but I have absolutely no relationship at all with the Republic of Indonesia or its troops entering West Papua'.

Our delegation, the Fakfak police commissioner, Metray, and the field police departed aboard the KM Maro, heading for the coast of Semimi in Etna Bay. In Etna I did not want to disembark. HPB Peters invited me to get off, but I objected. I wanted the resident, commissioner, and police to check my home and office, to see if I had stored there any documents from the Republic of Indonesia to introduce the troops of a Lieutenant J.A. Dimara disguised under the name of Mampioper. But the police commissioner boarded ship to persuade me, then forced me to get out, taking the necessary suitcase and clothing to come along to Kaimana.

\section{COMING BRINGS GOOD LUCK}

On 11 December 1951, after completing my education at the Bestuurs Opleiding School (BOS, Administrative Training School, which later changed its name to OSIBA) I was appointed as a civil servant and placed by the director of home affairs in Kaimana district, at that time still known as onderafdeling Fakfak. For that reason, before heading to my job location, I reported to the resident of West Nieuw-Guinea in February 1952. In the interim, I served on the staff of the resident of West Nieuw-Guinea in Sorong-Dom.

In February, an official meeting of all of the HPBs across the residency of West Nieuw-Guinea was held. Upon arriving in Sorong I reported to the resident of West Nieuw-Guinea, Mr. Maurenrecher. After reporting I received instructions to report to my superior, the HPB of Fakfak, who was in Sorong at the time. Since all the HPBs would be returning to their respective regions, I would join them on that occasion. 
Thus, I reported to the HPB of Fakfak, Mr. J.H.F. Sollewijn Gelpke. The resident, Mr. Maurenrecher cast off for a tour to Fakfak, stopping in Teminabuan to drop off the HPB of Ayamaru, Mr. Meyer ${ }^{\mathrm{il}}$ and his entourage. The journey to Fakfak went through Pisang Island. When we arrived in Fakfak, Resident Maurenrecher was welcomed with an honour guard ceremony by the police, civil officials and armed forces of Fakfak. The HPB of Fakfak directed Mr. Tamaela, the Fakfak district head to give me an opportunity, as a newly arrived civil service officer for Kaimana, to provide information and direction to the village people and school students in Fakfak district.

I visited villages in the vicinity of Fakfak city, up to Sipatnanam in the west, and villages in the Karas archipelago in Sabakor Bay in the eastern part of the district. In each village I emphasised the development of healthy homes with the support of a good environment; efforts to improve gardens by planting food crops that could be continually sustained so that the food needed would not dwindle; and processing a good variety of foods consisting of tubers, vegetables, fish, and animal flesh in order to improve nutrition.

After World War II, there was a great lack of personnel to perform government and private sector jobs. In short, Papua still needed a lot of staff; many jobs were waiting for workers. Each region competed in pursuing education and employment, so the Fakfak area too had to endeavour and work so as not to lag behind the other regions. It seemed that the direction I gave them made sense to the residents and teachers and schoolchildren. Moreover, the one giving them direction was someone who was Papuan himself.

Kaimana and the natural environment around it were protected by hills and craggy mountains. There was land and a white sand beach with a beautiful coral reef, surrounded by the blue waters of the ocean, which were clean and calm-looking in the cool season, but unfriendly in the season when the waves were choppy, because of both the westerly and easterly winds. It had a good harbour, so during the World War II period, Japan installed a great many sea mines in the Kaimana harbour, so that the ships of the Koninklijke Paketvaart Maatschappij (KPM, Royal Packet Navigation Company) or patrol boats and other merchant ships could not stop at the Kaimana harbour. So the KPM unloaded goods

1 The Indonesian edition of the book says Meijer here, but this is likely a confusion of F.E. Meijer, 
and loaded export products such as copra, bia triton (trochus shells), alligator skin leather, damar resin, and so forth on the island of Karawatu near Adi Island. And the KPM transported the goods from Karawatu Island to the coast of Bisijari Bay, which was calm in all weather as well as being close to Kaimana. From here the KPM again unloaded goods and loaded export products.

Meanwhile, the Koninklijke Marine (Royal Netherlands Navy) was cleaning up the sea mines left by the Japanese army in the port of Kaimana. Finally, on 5 April 1952, the KPM entered Kaimana harbour for the first time since the outbreak of World War II. Incidentally, it was on this KPM ship that I rode and entered Kaimana. The morning atmosphere of the sea and air was calm. The sun was shining all along the coast of Kaimana, illuminating the blue sea. Entrepreneurs and government officials were getting ready to tend to the unloading of the ship. The beach of the port was crowded with people watching the KPM ship coming in. I was received by staff from the office of the district head of Kaimana. The district head, J. Sokurat, was ill. The village chiefs welcomed me with the greeting: 'Tuan Bestir brings good luck, so your arrival brings the KPM into Kaimana for the first time in 10 years.' In Kaimana I conducted a tour of the coastal villages of Kaimana, Namatota, Sisir I and II, Arkasi, Maimai and Lobo. I visited villages in the Kambraw area, as well as visiting villages in Arguni Bay to provide direction on caring for the environment, food nutrition, health and education.

\section{THE MANGGERENGGA MOVEMENT}

During the World War II period the area was affected by the problem of the cargo cult, which in the local language is called manggerengga. Its emergence coincided with that of the koreri movement in Biak. Therefore, on every visit I advised the people about the idea of obtaining wealth that forms the background of the manggerengga movement ${ }^{2}$, and how one could actually achieve it. That is, one must work hard, be diligent and obedient to the government and to the Gospel through the church, in

\footnotetext{
2 The cargo cult centred around the belief that wealth could be obtained from beings that flew through the sky in a canoe. This idea of obtaining wealth was cleverly 'translated' into Christian values and adherence to the government's modernisation programmes.
} 
order to achieve results that can bring well-being in life. Because welfare and prosperity would not come about on their own. Because of that, they must develop their villages into permanent settlements. And if there were enough children, schools could be opened, so that they could go to school. Because if they did not go to school they would lag behind the other regions.

The manggerengga movement caused the government to take strong action against its followers. They were afraid, and their fears had been compounded by the acts of cruelty of the Japanese army in Kaimana in the past, making them even more fearful of the current government actions. Therefore, my intention in coming was to free the community of the burden of fear. I persuaded them that since the end of the war, Papuans everywhere had been struggling to get ahead, and that their children could now attend school to become teachers, police and employees of any kind, or become a bestir (civil servant) like me, and there were still many more jobs to be done that required the young men and women of Papua to go to work.

My explanations captivated the people. So I went from one village to another, and almost all the residents came together with me, although I did not invite them. After I found out that kampung Taruatu was the centre of the manggerengga movement, I wondered what kind of reception I would get from the community there. As it happened, we were welcomed with adat dances and singing. And the atmosphere seemed to be just as it usually was; there was nothing about the atmosphere that threatened or impeded the government. It was explained to the people that the way to move beyond the manggerengga beliefs lay in being obedient, listening to the government and building good and healthy villages. That was clear and certain, while expectations based on the manggerengga movement, that intelligence and all the necessities of life would just come by themselves, could not possibly come true.

\section{THE GPM TEACHERS PROTEST}

I also provided information on things like adat songs, handicrafts, and other good adat-cultural customs that should be maintained. Whereas adat that was not so good should be omitted, for instance, singing war songs or singing to ridicule other clans, which gave rise to clashes and 
fights, should be forsaken. I advised them to work wearing loincloths, and that on Sundays or other holidays, they could wear clothes.

These things were supported by the HPB of Fakfak, J.H.F. Sollewijn Gelpke. We went into the field together, and he provided directives on singing and dancing: that in adat dances, using original matching props was far better than wearing modern clothing. But if you carried bows and arrows and spears while singing and beating drums, clearly that was an inappropriate kind of adat dance and culture. The directive on clothing was not meant to return us to ancient adat. Neither was it a ban on following new developments, nor a ban on wearing clothes, shoes and so on. Remember that continuously wearing dirty clothes on the body brings skin diseases, so they must be replaced by clean ones, and the dirty ones can be washed.

These appeals were protested by teachers of the Gereja Protestan Maluku (GPM, Maluku Protestant Church), on the grounds that the HPB of Fakfak wished to bring the people back to their ancient customs and did not like it when they wore modern clothing and such. These objections raised a fair amount of tension. I confirmed that as staff of the HPB and as a Papuan I would not prohibit Papuans from wearing modern clothes, but nor would I prohibit them from wearing loincloths and adat attire in everyday life.

I agreed with the HPB's directives, since it was I who had initiated the programme to prevent all Papuan customs and culture from disappearing, as had already happened to the arts of sculpture and carving. Fortunately, in Saireri/Geelvink Bay, now Cendrawasih Bay, the art of boat painting still existed, although the art of sculpting on adat youth houses (rumsram) had already vanished. Ultimately, the issue did not go on for long, as the government at higher levels also condoned their development. Things that supported the good of the community could be upgraded, those that were unfavourable should be improved. I introduced the issue as a poem in the monthly illustrated magazine in Netherlands New Guinea called TRITON. The poem with its rhyming style was as follows:

\begin{tabular}{|l|l|}
\hline Sauh adat penambat adat kekunoan? & Adat anchors, ties to the adat of olden \\
Sauh adat penambat adat kebaharuan! & times? \\
Tagal itu marilah kawan sekalian & Adat anchors, ties to the adat of new times! \\
Sebagai keluarga majalah Triton & Therefore, come all readers of Triton \\
Tjamkanlah adatiadat kekunoan & Pay attention to the customs of olden times \\
\hline
\end{tabular}




\begin{tabular}{|l|l|}
\hline Sebagai tjontoh suling bia Triton & For example, the triton shell flute \\
Demikian tampak pada foto & Similarly as shown in a photo \\
Di Semimi-Etnabaai satu tjontoh & In Semimi-Etna Bay, an example \\
Pertemuan senjata kuno dan moderen & Of a meeting of ancient and modern \\
Dipakai bersama menjamin keamanan & weapons \\
Itulah parang-pisau-panah-busur & Used together to ensure security \\
Pistol automatis-jungleikarbijns- & That's machetes-knives-arrows-bows \\
mauser & Automatic pistols-jungle carbines-mauser \\
Pakaian putih-hidjau-tjawat-topi pet & White-green clothes-loincloths-caps \\
Pendatang takut lari rasa hutan adalah & Immigrants run away scared, feeling \\
sempit & suffocated by the forest \\
Lain dari senjata kuno tersebut & Unlike those old weapons \\
Menjanji adat dengan tifa tidak ribut & Sing adat songs accompanied by soft drums \\
Itulah talenta dari yang Abawi & These are endowments from the Ancestors \\
Perbaikilah untuk hormat Bapak & Improve upon them to honour the Prophet \\
Samawi. & Abraham. \\
(Triton Magazine no. 7, 4 July 1958) &
\end{tabular}

\section{DISTRICT HEAD OF ETNA BAY}

I saw good prospects for the development of Kaimana district. I began encouraging kampung Tjoa-Matoa near the Utaram airfield to clear plots of land and plant coconuts. The area around the airfield site was still forested at the time. The field had only recently been cleared by the Japanese and was not yet ready, but was bombarded by American bomber planes, so it was abandoned. Efforts to develop the community in Kaimana district were discontinued; only the residents of kampung Tjoa-Matoa planted coconuts as a future source of livelihood. The rest had not been addressed - which is the reason I was transferred to Etna Bay.

Before the working visit of the resident of West Nieuw-Guinea, Mr. Maurenrecher, together with the HPB of Fakfak, Mr. Sollewijn Gelpke, I conducted an orientation visit to Etna Bay, as the district head there, Mr. Hatumesen, was going to be transferred to Kaimana.

In November 1952 I was appointed as district head of Etna Bay. As there was no other kind of transportation to connect to Etna Bay, the journey was made using the sailing boat, Tjing Cirian, owned by a Chinese businessman who transported goods and agricultural produce from Etna Bay to Buruai, Kainantu, and Arguni Bay. The journey to cross the distance from Kaimana to Etna Bay by government patrol boat usually took nine hours. But by sailboat it took three days. Moreover it 
was during the transition from the season of the east wind to the season of the west wind.

On the third day we arrived in Nanesa, before Semimi, the district capital of Etna Bay. It was already evening and the tide was low, and because the current flowing out of the bay was very strong, we dropped anchor and spent the night there. It was almost afternoon when the tide rose, and the sailboat followed the backflow into the Bay up to Semimi. The home of the district head was made of fruitwood, with sago frond (gaba-gaba) walls embedded in the ground and clamped with wood. The gaba-gaba windows were assembled with rattan rope and served as hanging shutters to cover the window openings; the roof was made of thatched sago leaves. The floor was earth with no cement, but the bed was built on the ground. The natural state of Etna Bay from the beach to the interior was a marshy plain (Lakes Manami, Erega and Jamor). The population of the Miere hill tribe lived on the northwest side of Lake Jamor in Sisyara and Boko. On the east side lived the Yabi tribe, in Akakori and Isadiso in the headwaters of the Wanggar river, in Maramami, Jereijepa, on the south side of Mount Menou/Wijland, and in Gijo in the Charles Louis Mountains.

\section{FOLLOWERS OF ISLAM IN A CHRISTIAN SCHOOL}

The coastal population of Etna Bay inhabited the marshy lowland areas of Mimika Bay (the villages of Nanesa, Tarera, and Omba), Kowiai (Tanah Merah Bay) and Semimi, Mur Island (Mairasi) as well as the swamp areas (lakes: Grimora in Manami and Erega); and the Omba Pamuku tribe also lived in Manami and Lake Jamor. The villages in Etna Bay that already had primary schools were Semi, Tarera, and Omba, while the others did not. In Jamor and Manami there were Gospel teachers of the Protestant Christian faith. The residents of Kampung Monda in Tanah Merah Bay embraced Islam. So, in Etna Bay there were both Protestant Christian and Muslim communities, and all of them had good, mutually cooperative relationships. The children of kampung Monda (Kayu Merah) attended the Sekolah Dasar Yayasan Persekolahan Kristen (SD YPK, Christian Schooling Foundation Primary School) in Semimi.

Meanwhile, the mountain Mairasi and Yabi people had absolutely no ties yet with the government or elements of the church. I was the 
one who first initiated contact with the Miere people in Sisyara-Boko, the Yabi in the Wanggar River headwaters and the Yabi in Titinima and Korou on the south side of Mount Menow. The population of the coast and swamps were proficient at boat making, but they could not make wooden logs to erect their own houses or school buildings. Their staple foods were sago and fish, and they hunted boar meat incidentally. The swamp areas were quite worrisome because there were a great many mosquitoes. There really were good places to settle to avoid the danger of mosquitoes, but they were far from the sago swamp habitats where the people got their food. There was enough land available that was good for horticulture with food crops and long-term crops, but all that was too far beyond their understanding.

Had we imposed new developments outside their habits, it would have been like forcing goats to eat meat. Or forcing lions to eat grass. We tried to direct people to make good homes for themselves on the coast. To build good houses, which, even if they had no walls, should be located on ground that was dry and high. Eating sago was fine, but it should be eaten together with fish, vegetables, and coconuts to provide good nutrition for the body.

In this region there were no health or agricultural workers or police, and so on. As the district head I doubled in these jobs, especially in the field of health. Many diseases were found in the villages, such as malaria, bronchitis, pneumonia, diarrhea, and others. We were equipped with the necessary medicines to treat old or new wounds as needed for first aid for accidents. If we arrived in a village and were informed of people who were seriously ill, we could be certain it was bronchitis or pneumonia or another common disease for which adequate medicines were available. Thus, I could not leave any village quickly because so many people were ill. Praise God that we could help all of them. It even went to the point of helping women give birth to babies; the teachers were not likely to help, so I was asked to assist them.

ASSISTED BY A CHINESE MERCHANT

There was no physical development yet in Etna Bay. But permanent settlements among the mountain Miere and Yabi had started up, although there were not yet any teaching staff to provide education in the moun- 
tain areas. This had only recently been proposed for the area around Lake Jamor. The village residents were directed to fill the schools in the villages where there were Gospel teachers and trained school teachers. The people were also asked to collect forest products such as damar resin and masoy bark, as well as alligator skins, to supplement their incomes so they could meet their needs and buy mosquito nets in order to reduce malaria mosquito bites.

A permanent police hostel and district head's office began to be built. On this I worked together with a Chinese trader in Etna (Tan Kok Tjon) who had handicraft skills. It was also expected that Tan Kok Tjon would educate youth so they would master log making, planing, chiseling, and drilling. So they could build houses.

I also recruited young people from Etna Bay to apply for general police studies, and they succeeded in getting in. One of them joined the OBM (Oost-Borneo Maatschappij) \& FSCNY (Freeport Sulphur Company New York) expedition to the Carstensz mountains in 1960. This one district required many things that had to be done, but were not supported by the funds, labour and other resources needed in the effort to develop village communities. Therefore, efforts to help the inhabitants were made by directing them to find and gather damar, masoy bark, trochus shells, and alligator skins, which were sold to two Chinese Indonesian merchants in Kaimana who had stores and bought such products from people.

One thing that helped these trading activities was that every two weeks, the resident, HPBs and district heads all received news on consignment prices in the world market through the governor, namely: the prices of copra, triton or trochus shells, alligator skin, copal/damar resin, nutmeg, mace, etc. on the markets in London, Paris, Amsterdam, Singapore, Hong Kong, Shanghai, Kobe, Tokyo, and other places.

Additionally, I surveyed the trails to Kaimana, Geelvink Bay (Nabire and surroundings), to Menou, and Monemani-Wagete and Enarotali in Paniai. We departed from Kaimana by ship and tried following the Omba River into Lake Jamor. The cruise reached the middle of the coast and Lake Jamor, but did not proceed any further as the ship was soon recalled because it was needed to help transport the police to Fakfak.

Kaimana had become a sub-division. So HPB E. van Voskuylen and I and the police conducted a patrol from Etna Bay. We began following the Jepre River on the northwest side of Lake Jamor heading toward 
SisyaraDBoko (Miere), onward to Sara-Tanwata-Farenyau I \& II, stopping in Arkasi or Nanggaromi in Sisir II, Kaimana. However, some of the police fell sick and the guide to Mairasi was in Wondama Bay (Wasior), so the patrol turned back from Sisyara.

Lake Jamor was originally called 'Urubika', which means a large pool. It was located at an elevation of 30 metres above sea level. The Omba river, which flowed from this lake to the coast, emptied into the sea at kampung Omba. The tributaries of the river - called the Japre and Wandu or Napuri rivers in Grimora language, while the Jabi (Mapia) Mee tribe called them 'Kepurey', that is, waters that came from Mount Menow. The natural conditions of the area were good for the development of food crop cultivation, but in the lowland areas the mosquitoes were very numerous. In the mosquito season we ate under the mosquito netting even in the daytime.

The inhabitants' houses were platforms set on stilts, but had no walls. The purpose was to make it easier for the wind to expel the mosquitoes, or for us to repel the mosquitoes by lighting coconut palm frond torches at night. There was a plan to move the people to the mountains where there were fewer mosquitoes, but this was blocked by the obstacle that the staple food they consumed was sago, which only grew in the lowlands. They could not be shifted in the near future to cultivating tuber crops. They were used to eating tubers, but only as a variation of sago as their primary food.

\section{THE REVEREND AND THE FATHER}

Following the patrol of the HPB of Kaimana, F.H. Peters, we arrived in Keghete. Here there were two school teachers, namely, Joseph Makai of CAMA (Christian and Missionary Alliance), and a teacher of the OFM (Order of Friars Minor) Catholic mission. The people addressed the Protestant school teacher using the term, Guru Pendeta, while the one from the Catholic mission was called Guru Pater. These terms of address were based on the designation for clergy of the Protestant Church and Catholic Church. We divided the nights we spent in Keghete by sleeping one night at the house of the Protestant teacher and the next night at the house of Catholic teacher. 
The village chief came to us and asked, 'Bapa Bestir, I am wondering, before, when Guru Pendeta and Guru Pater had not yet come, we villagers had good relations. We sat around talking, hanging out together. But after Guru Pendeta and Guru Pater came, we did not live together anymore. The Pendeta's people (Protestants) were on their own, the Pater's people (Catholics) on their own. What is more, the Pendeta's people don't smoke cigarettes anymore. The Pater's people smoke cigarettes. People are more fearful now, don't dare to be close to one another. How do people live over there, in the city?'

I replied, 'there's no rule prohibiting the Pendeta's people from associating and living together with the Pater's people. Let's see, yesterday we stayed at the home of Guru Pendeta, and we prayed together with Guru Pendeta and Guru Pater. Tonight we are sleeping and eating together with the Catholic teacher, the Protestant teacher, and their wives. Kepala kampung, you can see us right now, sitting, talking, telling stories, and eating. You are also eating with us, and no one is prohibiting it.'

'Indeed everyone prays in their own houses of worship. After praying, they live together as usual. It's only the villagers themselves who think there are restrictions. Basically, there is no difference. If you smoke, it's not prohibited either. Although it really is advisable not to smoke because it can cause disease. Kepala kampung, do you understand all of this?'

He replied: 'Thank you, now I understand. I was used to seeing Guru Pater and Guru Pendeta sitting and talking together, so I wondered why us villagers were not sitting together anymore. We ourselves couldn't understand it, and we didn't ask our teachers about it.'

Since he understood, I told him: 'in the future, if the Pendeta's people want to build a church, then the Pater's people should help out so it could be done quickly. And vice versa, if the Pater's people want to build a church or a teacher's house, then the Pendeta's people should also help to get it done quickly, and so you will move forward in everything you want to do. Don't compete with each other over bad things, but rather compete to build houses, churches, to make gardens to produce good food for the people of both churches (Protestant and Catholic), in order to live safely and happily. Such is the road God wishes you to take.' 


\section{CLEARING THE AIRFIELD}

I was assigned to clear the forest and clean up all the land for an airfield, and to check for bombs released by the American army that were still in the ground, not yet detonated. I also surveyed the road that connected the airfield to the coast, crossing the Tiba river and going down the hill out of the northwest tip of the Utarom airfield. In Kaimana I gathered together the youth of the Kamrau, Mairasi, Irarutu, Kowiyai, and other peoples, and advised them that now we were clearing and cleaning up the location for an airfield. We had to clean it up in two months' time. We had to clear the site to examine it for undetonated bombs so they could be removed.

After the area was cleaned up, the contractor came with a bulldozer, steamroller and other heavy equipment to create the airfield. Don't think that it was because the Indonesian army had now entered Etna Bay that we were making that airfield - for war. That is absolutely untrue. The issue of going to war or not, that was up to the Dutch and the Indonesians. The field was not for the Netherlands and Indonesia, but belonged to the land and people of Papua. When things were needed for development, they wouldn't have to wait for long, as the airplanes would come and carry or drop off the foodstuffs or drugs necessary to combat diseases and so forth. That was why it was not influenced by anyone else's issues, but done and attended to as I advised, in order to create

something that you, not by the Dutch or the Indonesians, owned. I camped out with the young people on site and in 14 days' time all the land for the airport had been cleared and cleaned up. There were over 30 holes containing leftover bombs in the field. There were three undetonated bombs, and they weighed between 300 to $400 \mathrm{~kg}$. The marines and Royal Netherlands Navy arrived from Biak, and they defused and removed the bombs from the airfield. The contractor from Hollandia used a landing boat to bring the bulldozer, steamroller, truck, and other things ashore, and began working on the airfield, and in two months the entire runway was bulldozed and flattened. I checked the road and suggested it would be best for now to work on the road through the beach as it would be easier and cheaper. That would leave room for the cost of building an overpass above the Air Tiba river using iron pillars. At a later date, a road in the hills on the north side could be opened up when 
there was enough budget for that, so the maintenance costs would not be a burden while the air flight traffic to Kaimana was not yet so busy.

While I was in Kaimana, the resident of Fakfak, Mr. Eibrink Jansen, kept harassing me. He would call and ask me why I was not keeping an eye on the people who were 'merah-putih' ('red and white' or pro-Indonesia) in Kaimana and Arguni. I was a civil servant and did not have the intelligence task of community surveillance. Because these people were my people. It was not for me to determine their identities: you are proIndonesian, or pro-Dutch, pro-Japanese, or pro-Satan.

I did not discriminate among the people. As long as they wanted to listen and did not create criminal cases and so on, they were all my people. If some were pro-Indonesia, it was not my job to interrogate them, especially if there was no clear evidence and they were not caught redhanded. That was the special task of the state mechanism that handled such matters. 'Yes, but why are you not monitoring the RMS (Republik Maluku Selatan - South Maluku Republic) people?' Mr. Jansen pressed on. 'Your Excellency, Mr. Resident, I would like to ask, are those RMS symbols being circulated made in Kaimana, Fakfak, Biak, Indonesia or in the Netherlands! I happen to know they are all made in the Netherlands. If the Netherlands is producing them, that means the Netherlands supports the RMS, supports the Red and White Republic of Indonesia! If so, the Netherlands should not be deceiving Papuans in all sorts of false ways; it would be better for the Netherlands and Indonesia to kill off all of the Papuans; then you all would own Papua, realising the centuriesold plan of the Netherlands and Indonesia to let the people of Papua be displaced and forgotten.'

\section{THE RESIDENT APOLOGIZES}

The work on the airfield was 75 percent done. The road connecting the airfield with Kroi was completed in six days. The iron needed to build the bridge over the river was brought in from Hollandia. Half of the Indonesian troops that had entered Etna Bay had surrendered and were arrested and sent to Hollandia. That left J.A. Dimara alias 'Mampioper', who was still being sought in the forests of Etna Bay.

Resident Eibrink Jansen, who was on a working visit in KokonaoMimika, was travelling through Etna Bay and arrived in Kaimana. 
He instructed the Kaimana HPB, F.H. Peters to summon me from the airfield to appear before him. I replied that if he had come to talk about other things I could, but if it was to talk about the current incident in Etna Bay, it would be best not to bother because it would only be a waste of time and thought.

But I was summoned to come in peace because I was not guilty. I was forced to leave for Kaimana, to the residence of Mr. HPB. When I went inside the HPB's house, Resident Eibrink Jansen came out and embraced me and said that it was true that the man who had come was not Mampioper, but First Lieutenant J.A. Dimara. 'I apologise,' said the resident, 'because you are not guilty.' No, we Papuans did not lie about what was true. Before any evidence was obtained, I had said that indeed there were Biak and other brothers of Papua living in Indonesia, but I had no blood brothers or family in Indonesia. Yet my name was used by Dimara to influence the village people.

Any fool could recognise such tactics. But the resident had not believed my words. Although I worked very hard, he did not in the least bit appreciate me. Anyway, the matter was already done with and not worthy of further consideration. It was done, but it left a stain that would not be erased from my memory all my life. Subsequently, he stated that my work on building the airfield had run faster than the plan anticipated. So I was asked to return to Etna Bay to restore the life spirit and work of the people there.

\section{LIEUTENANT DIMARA IS ARRESTED}

In August 1954 I returned to Etna Bay, because the Nederlands NieuwGuinea Petroleum Maatschappij (NNGPM, Dutch New Guinea Petroleum Company) was beginning oil drilling preparations there, in Weribi. I conducted a tour to advise and encourage the villagers not to be afraid, because they were not guilty. If they had been ordered by the Indonesian military under the leadership of their commander, J.A. Dimara, to take them by boat, now they could go to work as usual. The work for the people of Manami and Gariau in Jamor was to build a school house, since we had already reported that a school was to be opened in the area. Meanwhile, J.A. Dimara and three of his men were still in hiding in the forest. Most of the marine and police patrols had 
already returned to Kaimana. One police platoon had remained to look for them. I suggested to the commander of the police that they were probably not in the woods, but still roaming the former sites of the patrols along the Omba river between Kupai and Napuri. Because that's where the field huts of the villagers were. Around each field hut enough edible hibiscus leaves (sayur gedi) were available, and it was the fruiting season for breadfruit trees, all of which could serve them as food.

And I was sure they would not put up any resistance, because based on the most recent information, they had no weapons. Because Simon Auba Pamuku and his gang from Manami had gone down and run into Dimara, who stalled them by asking to follow them to Etna and saying they would surrender to the government. But in the middle of the Omba river, while they were cooking food, Dimara tried to steal a boat to get away with his three men. But he fell into the river, and then Simon stabbed him with a spear. Dimara swam, wounded, to the river bank and removed the spear that had pierced through his hand, while Simon and his small group fled in two boats, leaving Dimara and his three men behind. Meanwhile, Dimara's pistol, carbine, and axe were in the boat that Simon took away. So it was clear that Dimara and his three men had no weapons. Moreover, Dimara himself could do nothing with a wounded right hand.

Therefore, I advised the chief of police, Huisma, that he should deploy each member of the police along with three village people at each location in Napuri along the Omba river and they would eventually meet up with them. There would be no resistance. And I asked that they be captured alive and that nothing be done to them. Huisma accepted my advice and guidance and the police managed to find them and bring them to Etna Bay. There we treated Lieutenant Dimara's wound; then he was taken to Kaimana and subsequently sent to Hollandia.

After this incident, the police were stationed at a post in Etna district. While waiting for a permanent police dormitory to be built, I emptied an office house to serve temporarily as a police station. Meanwhile, the NNGPM in the oil drilling site in Weribi built a $15 \mathrm{~km}$-long road leading to the to drilling centre. Unfortunately, the NNGPM parties did not invite us or the the HPB of Kaimana to attend on the day of the drilling, nor were any of the adat leaders who were in charge of indigenous land rights (hak ulayat) invited to attend. 


\section{REFUSING THE INVITATION OF THE NNGPM}

After the drilling that was not attended by local government officials, NNGPM invited us to come to eat together as a sign that they were doing the drilling that was in progress. I objected and refused the invitation, because they had not honoured us in their drilling ceremony. So I did not come to eat with them as a group after they punched holes in the earth of Miere and Bai. Lest the ancestral spirits of the land become angry with me. If oil did come up as a result, I and the adat leaders would give tribute to the ancestors.

The development of Papua demanded results, but if etiquette and good manners related to the excavation of natural resources were ignored, then expectations about what was to be achieved would be empty as well. In point of fact, after drilling into the bowels of the earth over a span of close to two kilometres or more, there was no sign of oil and eventually the operation was closed.

No progress had been made yet, in a physical sense, for the community of Etna Bay. But mentally, there was progress. There were young men who had gone into police studies and graduated and been accepted into the police corps. Also, some school children from Lake Jamor had passed the entrance exams to get into the Papoea Vrijwilligers Korps (Papuan Volunteer Corps). Villages around Lake Jamor and Manami managed to get schools with subsidised teachers' salaries. Village schools were given subsidies and managed by the Protestant Church and the Catholic Mission.

The government of Netherlands New-Guinea did not establish government-owned state schools. Primary, lower secondary and upper secondary (HBS) schools were left to the private sector. The government only dealt with official vocational schools such as schools for administration (civil service), health, finance, agriculture, shipping, police, and so on.

Subsidized schools were not provided easily, but based on research and long term monitoring on the conditions in a community, the size of its population, the number of families with children ready for schooling, the prospective school and students who would come to attend the school; the number of fertile families, and of young men and women who would start families and bear children to fill the school; the socioeconomic responsibilities of the community to support village liveli- 
hoods, food, clothing, health, housing, and the physical development of the village. Were they ready to assume responsibility for the physical construction of the school house, school furniture, and teacher's house? In that period, funds to meet all of those needs were lacking, while the costs of teachers' salaries, school books, and other educational technology of the schools were borne by the government. All proposals, accompanied by reports and recommendations from the district head, were sent to the HPB and district school supervisor to convince the government or the Education Department to give subsidies to the private schools of the Catholics or the Protestant Christian Schooling Foundation. Whereas for Jongens Vervolgschool (JVVS, follow-up school for boys), Lower Technical School (LTS), Junior High School (Primaire Middelbare School or PMS) and HBS (Senior High School), the buildings, furnishings, school books and other things were covered by the government, and the schools were managed by the Catholic and Protestant foundations, using the budgets respectively granted to them by the government. This was how the physical construction costs of these upper level private ${ }^{3 \mathrm{i}}$ schools were subsidised by the government.

Meanwhile, the construction of the houses and schools, together with their furnishings and maintenance, were the responsibility of village communities, supervised by the government (the district head) in each district. Government parties assisted on an incidental basis with materials they did not have, such as nails, shovels, saws, chisels, and hammers. Likewise, the building of the teacher's house was the responsibility of the village community. The house of the district head was built with fruitwood and its roof from sago palm leaves. For lighting, oil lamps (lampu lentera) were first used, and later, pressurised kerosene lamps (petromaks). There were no concrete houses with electric power or radios. All you could hear were the sounds of birds and crickets, or sometimes, the children of the village crying or shouting for joy. Or the traditional feasts of the village people with their roaring drum beats. On other days, you could hear the sounds of school children singing simple but interesting songs in the stillness of the remote and quiet hamlets.

\footnotetext{
3 'Private' here means run by the churches. But in fact these schools functioned as if they were public schools, as the church foundations were subsidized for the material construction, while the teachers were either paid by the government, or (more often) by the church.
} 


\section{MOVING TO A GHOST TOWN}

Fakfak was the next post I was assigned to after serving in Etna Bay. Together with the employees and youth of Fakfak city, we formed a Fakfak municipal community team in addition to the police team, marines, and the Opleidingsschool voor Dorpsonderwijzers (ODO, Training School for Village Teachers) of the Mission and the ODO of the Majelis Pendidikan Kristen (MPK, Christian Education Council). All of these helped to develop Fakfak into a bustling town, like an eagle's nest atop a rocky hill. After serving there for five months, Resident Lamers summoned me and said: 'You will be transferred to Kokas. Kokas is a small town that is old and dying, as if it has shriveled up. I hope you can go and revive it. There is already an assistant administrator who is old and experienced in serving there, but he has not brought the place to life. I hope you can resuscitate it. Good luck on the job,' said Resident Lamers.

'Thank you for your trust, Sir. I will try to do it to the best of my ability, but I myself will not succeed, without the support of my superiors, in convincing people to wake up from such a long sleep.' I visited all the villages in the district. It seemed that produce was available in most of the district, but why was it that none of the inhabitants' homes were decent? There was domestic nutmeg (Papuan nutmeg), damar resin, and Mollucan ironwood (kayu merbau) and ironwood timber. All of it was coordinated by the Forestry Department and the Onin Sehati Cooperative of the raja (ruler) ${ }^{4 i}$ of Rumbati, which was supported by a small ship with a ten ton carrying capacity, which doubled as a tug boat to pull the logs, tied together as rafts, downstream. The Papuan nutmeg could be harvested twice a year. Yet no significant revenues seemed to come to the community. Decent houses and valuables like sewing machines and other belongings appeared to be lacking among the villagers. Through research it was found that the residents who owned the nutmeg trees had been burdened by debts to the merchants for many years, from before the war until after the end of the war. The debts of the parents were handed down to their children.

4 These raja were Ternatean vasals, often entrepreneur-traders alias local rulers of mixed TernateanPapuan background. The Ternate sultanate had ruled over the coasts of Papua in pre-colonial times, and the institution of the raja remained long after the power of the sultanate was displaced. 
In a meeting with the village and community heads we asked them not to sell individually to the merchants. Also, the merchants were not allowed to buy directly from the villagers and were never again to place the villagers, as the owners of the nutmeg, into debt. Anyone who had debts was asked to register themselves and their debts. The merchants were not allowed to exact payment for old pre-war debts. What they were authorized to do was to charge them for post-war debts, once the administration began to run normally in Kokas. There would be no dealings with anyone who violated the prices established for the nutmeg tree owners. It would be at their own risk. Debt loss or debt bondage (ijon) negotiations were prohibited. All agreed that beginning in the 1956-1957 nutmeg season, those who had few nutmeg trees would be justified in receiving a voorschot (advance) of no more than fl. 25 (twenty-five guilders), while those who had substantial nutmeg plantations would receive fl. 50-fl.75. Anything in excess of these standards was to be be regarded as gifts to the community and submitted to the office of the district head after the person concerned had notified the village chief.

Bans against harvesting in certain seasons (sasi) for nutmeg were lifted and the government regulated the auction house prices. In each place, staff of the district head were present to manage the auctions. Any dealer who offered a higher price was the one who bought. No other prices fell below that offering price. If there were traders who offered prices higher than the official price, the people should not believe it because no one was monitoring his conformance to the official price while settling debts.

The HPB and the resident protested these methods, because, they felt, would it not be difficult for me to control them? I knew it would be hard, but I had to do it to eliminate trade practices that were not beneficial to the community as well as being unprofitable to the traders. Because if nutmeg is not really ripe when it is picked, then its value is not as good. I spread out the members of my staff: sending Olaf Bertels, the administrative assistant officer to the Rumbati region; Pattipi and Nicolas Tanggahma to Kokas and Pasar Pendek; and Dorus Rumbiak to Pasar Panjang.

That year the prices of nutmeg and mace were good in the world market, with the result that all the debts were paid in full. And all the merchants were relieved because the debts to them were paid in full. The residents were happy because this time they received cash in hand and their debts had been redeemed. The debts of the village chief, 
Homorkokma in Pasar Panjang were paid off and he received fl. 30,000 guilders in cash. He renovated his house, bought a sewing machine and other goods. Due to this success, Resident Knödler ordered me to take over the supervision of Mollucan ironwood timber logging for log exports and settle the debts of the public to the Department of Forestry, and of the Department of Forestry to the merchants. Ironwood logging was done without using dozers (tractors) for pulling, but by constructing a path of slender stems, ${ }^{5}$ over which the logs were hauled (to the waterfront), a method known as perangung in the local language. This method was costly and it took many workers to get the logs to the coast. A way of working that was very hard.

\section{CRAZY WITH DEBT}

On the coast there were no barges for loading the logs. Rather, a large raft was made to float the logs (which would otherwise sink), and in this way, dozens of ironwood logs were loaded on top of it and then dragged by tugboat to the ship. They had to wait for the date the KPM ship came in to load. The logs had to be measured, and each person had a few wooden logs measuring a few cubic meters. The Forestry Department personnel took the measurements, and the staff of the district head recorded them and at the same time, calculated the price. I assigned Bertels in Rumbati, Dorus Rumbiak and Tanggahma in Kokas-Arguni.

After the timber was loaded onto the ship, the price was paid to each owner, which at the same time reduced his debt. Traders with foodstuffs and equipment, which the forestry workers brought for the villagers who cut the wood, were also there. Debts were settled and the remaining monies were paid out, and all the accumulated debts of the forestry workers, the wood cutters and the merchants who owned the goods on credit - such as rice, sugar, coffee, hatchets, machetes, and tobacco were paid off. One of the Forestry Department staff had even suffered a mental breakdown due to stress over his debts. After he was healed, he was moved to Kaimana.

That was the problem that was bringing apathy and fatigue to the village community and the merchants as well as to the technical imple-

5 These were the trunks of smaller trees in the vicinity of the ironwood that had no value as timber. 
menting officials who worked there. But such debt bondage provided no solution to help raise the living standards of the village community and the entrepreneurs, who were also suffering. The results achieved were not high quality and were in themselves causing losses to the government in the various development enterprises being implemented.

Nutmeg in Fakfak and Kokas, as mentioned above, brought results, but also gave rise to many problems. One of the problems was ijon or debt bondage. Another problem was the conflict that occurred, to the point of fighting, during each nutmeg season. The issue in Fakfak was an element of the class system, that is, of the dupyat or adat leaders. They brought workers from Inanwatan, Arandai, Teminabuan and Ayamaru to serve as their labor force, known as anak piara (a term for household help that literally means foster children) or 'slaves'. In the nutmeg season they picked the nutmeg of their foster fathers, the adat leaders, but the biological children of the adat leaders would not let them, so there were conflicts that had to be resolved all the time.

\section{THANKS TO BAT DROPPINGS}

I tried to bring about a rejuvenation of Papuan nutmeg, or the cultivation of Banda nutmeg. The raja of Arguni had several Banda nutmeg trees. They were already fairly tall, but not well maintained, so they were not bearing many fruits. I asked Raja Arguni if I might have the nutmeg trees so I could take care of them. I fertilized them and succeeded in sprouting seedlings and distributing them to the people in Arguni, Kokas, Pasar Pendek, and across Kokas District. Raja Arguni welcomed my request and I got bat guano from bat droppings from a cave on Ugar island and fertilised the three Banda nutmeg trees received from him. Within three months they bore fruit and were very bountiful. The three trees were so lush with fruit down to the ground that they almost snapped. The raja himself was very happy that the Banda nutmeg trees that were previously barren were now so dense with fruit.

I took seedlings to make a nursery in Kokas, then the resident came to visit Kokas and see whether or not my report was true. It appeared that the seedlings were thriving in Kokas. He visited Arguni and saw the nutmeg trees I had fertilized there. Raja Arguni himself explained what I 
was doing with his nutmeg trees, which he had considered unproductive, but were now growing and bearing fruit so well.

The Resident stated that it was a good initiative. And that he would instruct the agricultural expert consultant in Fakfak to take over the work while I continued to oversee its progress. He said that there were many other tasks I had to do. Unfortunately, the Iha people, who already had Papuan nutmeg plantations, were not responsive to planting Banda nutmeg. They said the Banda nutmeg was good, but bore fruit constantly, so there was no time to tend to their other gardens for food production. The Papuan nutmeg had a harvest season, which allowed time to cultivate taro or red beans.

In Kokas we repaired the drinking water pipeline, a legacy of the Japanese that had been damaged as it was hit by a bomb from an American bomber plane. The distance from the water source to the city was more or less one kilometre. Additionally, the distance to houses in Kokas, Sisir, Kokas Kecil was almost a kilometre, so in all, two or more kilometres of piping were required. There were no funds. I saw there were empty cartridge cases from the cannons fired by the Japanese army. I directed the people to collect the cartridge cases to be sold. Each piece was worth fl. 0.25 (guilder cents). There were no trunks, so we used empty drums to store them.

The HPB and the resident came to see to it that the numbers were sufficiently convincing and the resident promised to approach an Australian company that was coming to melt down the American planes dumped in Biak to buy the brass. The empty cartridges were successfully sold, and we bought pipes and snijdraad (thread tappers, to cut screw threads onto the ends of the pipes) to install drinking water pipes in Kokas as well as in Fakfak city.

There were no workers available to do the work. I did it myself, by training two permanent workers and deploying the youth in Kokas into working groups to install the water pipes and repair the water sources. They repaired the water tank damaged by the bomb. There was also a group that repaired the roads and bridges damaged by bombs. Another group cleaned up the city and a group that worked on the soccer field in Kokas and a Kokas team was established. This situation made the whole community and the entrepreneurs feel relieved.

The raja of Rumbati, Haji Ibrahim Bauw, told his colleagues, the raja of Kokas and Fakfak: 'Our Tuan Bestir is a youngster, but his talk is 
razor sharp!' We actually never played with power for its own sake, but for whatever we deemed good for the community. I did it in the interest of the community and reported it to my superiors.

\section{BOATS ARE THE SOLES OF THEIR FEET}

Communities in the two regions did not take initiative on their own to create the changes that were necessary. They performed routine jobs, cut down and pounded sago in the headwaters, and in the shark (mamen) season they caught the small types on the coast. The government established dorpsraden (village councils). The village chief served as the chairman, the school principal as the secretary, while the members consisted of leaders who could manage the interests of their village in the council. The village administration programmed things that would be good and beneficial for the community, such as the establishment of a school, a teacher's house, a church, and at the right times, cutting down timber and turning it into boats. Boats were vital to the inhabitants of Mimika, Etna, and Asmat. The swamplands were vast. There were no footpaths, so the boats served as the soles of their feet. Every family had to have its own boat. Life meant nothing if you did not have your own boat. People would not cry if their house burned down, but if a boat drifted away or was damaged, let alone capsized, they would cry. Because all their possessions, such as the machetes, knives, axes, pots, pans, clothes, and fabric they needed, were stored in those boats.

They were taught to saw Mollucan ironwood using cutting saws, and to protect the saws with files and sawtooth openers so they were always sharp and good for use. Eventually, each village chief had these tools, which their men used to saw wood and sold it to the government and the Catholic mission to build houses in Kokonao. In that way they earned money.

I saw that the plots of land around the villages could be planted with coconut trees and fruit trees. I brought coconuts from the island of Kelimala-Karawatu (Kamau) using the patrol boat, Willem Janz in Kaimana and the Tasman from Fakfak. Each family in each village received five coconut tree seedlings to plant. I also distributed rambutan, robusta coffee, and durian trees in each village; started experimental gardens for planting vegetables, rambutan and citrus fruits, robusta cof- 
fee, rubber and oil palm in Kiripau (Wania); and opened Akimuga as a agricultural project that later became the transmigration site for the Amungme tribe from Tsinga and Noemba as well as serving as a districtstatus government post.

I made contact with the Amungme residents in Carstensz. There was the drawback that the area was under the jurisdiction of the resident of the Central Mountains and the implementation of government there was under the HPB of Enarotali in Wisselmeren (Paniai). I noted that it was difficult for the HPB of Paniai to visit the districts of Paniai, Waigete, Tagi and as far as Moni and Mapia, let alone to go as far as West Mapia. It was I who made contact with them in Titinima (south of Mount Menau / Wijland) and Cyro (Charles Louis Mountains). What is more, Carstensz was very far and made for an arduous round trip (Enarotali-Carstensz). I felt that contact from Mimika was closer. The people in Carstensz could go to Mimika. In Mimika a Catholic mission had opened, and the health team for the eradication of yaws disease went up from Hollandia to Carstensz through Mimika. I proposed it would be better for me to contact them, and at a later date, when conditions were good and things were running smoothly, a better status for the area could be arranged. Finally, the resident and the governor both agreed that the area should be fostered by the HPB of Mimika. Many school children were sent to Kokonao, and subsidised primary schools were opened in Tsingga and Noemba.

In 1960 an OBM and FSCNY expedition was conducted whose management was entrusted to the HPB of Mimika. The district head of East Mimika, who supervised the exploration area that had not yet been brought under the influence of the government, including Carstensz, was responsible for the expedition. As it happened, I was appointed to take responsibility and lead the expedition.

\section{ACCUSED OF DIVERTING FREEPORT}

In the year Freeport Indonesia Incorporation (FII, now called Freeport Indonesia) began to operate, the company paid compensation funds to Pemda Tingkat II (second level local government) in Fakfak. The local government of Paniai in Nabire became angry, saying: 'This area belonged to Paniai and Nabire, but thanks to Mr. Mampioper, it is now part 
of Fakfak and they've got our money.' I scolded the local government concerned, saying: 'I have no intention of eating the people's money like you.' Instead, my intention was to ensure that the forgotten people in the area could be reached and assisted with efforts to improve their lot in life.

We did not use cars and airplanes in those days as we do today, but travelled on foot to develop the people there until Freeport came in. There was no committee. But I was specifically commissioned by the Netherlands New Guinea Government to take responsibility for the success of the expedition - until Freeport entered in 1967, violating the New York Agreement on West Papua. I was reappointed by the governor of Irian Barat (West Irian) to control the activities of FII in 1967 and onward, until it could operate officially in 1973.

My brothers, do not be offended that I diverted the region (from the Paniai to the Mimika administration), but please understand that this was the way I took to manage the community, and not to enjoy its immediate fruits. On the contrary, it was my brothers who enjoyed using the contributions from FII. Actually the province and the district misused the endowments of FII because they thought they were being given a gift to be shared among the officials to buy cars. This was one mistake of the Indische Comptabiliteitswet (ICW, Netherlands-Indies Accountancy Act), which has been used up to now by the Government of the Republic of Indonesia to oversee state finances.

Apart from the above-mentioned matter, an attempt was made to provide a source of revenue to the people by trying to produce salt fish in the villages of Otakwa and Maare-Pigapu. I helped with the salt, knives, machetes, and the use of traditional means of catching fish by damming the tributaries of the river at high tide. After the water receded the fish were blocked and just remained to be picked up. From the big fish, they made salt fish, while the small fish, shrimp, and crabs, they ate. Sometimes they sold them in the market we opened every Saturday in Kokonao.

From that market we bought fish, crabs, and snails to be sent to the local government in Enarotali (Wisselmeren) for sale over there, and with the sales proceeds, they bought vegetables, which they sent to the local government of Mimika in Kokonao. Because the salt fish produced in the villages of Moare-Pigapu and Otakwa was of fairly good quality, the Catholic mission bought it and supplied it to Paniai and Wamena in the interior. Most unfortunately, I was transferred and the official who 
replaced me did not continue these activities that could help the community. Furthermore, the Dutch-Indonesian situation in Papua contributed to the weakening of the budget and other efforts to develop the West Papua region.

I was placed with the Department of the Interior in Hollandia while following courses (applicatie cursus) at the OSIBA complex in HollandiaBinnen, in the location of the campus of Cenderawasih University in Abepura, Jayapura today.

The Dutch-Indonesian political turbulence became tense. Both nations treated the people of Papua as if they did not exist. During the period of the debates of the Round Table Conference in The Hague in December 1949, they did not hear the voices of the Papuan conscience. In the preparatory period, Mohammed Hatta in his discussions proposed that they surrender Nieuw-Guinea to be led by the Dutch. Similarly, in the time when the Kingdom of the Netherlands recognised the independence of the Republic of Indonesia at The Hague, Mohammed Hatta also stated that they surrendered Nieuw-Guinea to be led by the Dutch. None of the delegates objected, but Simatupang, who represented the armed forces, said that this could not be; Nieuw-Guinea had to be part of Indonesia because they had been equally colonised. A rationale with no foundation at all, because the Netherlands in fact had two different colonies. That is, up to 1950, the Netherlands colonized the Dutch East Indies (Hindia Belanda), then called Sunda Besar (Sumatra, Java, Borneo, Celebes), and the islands of Sunda Kecil (Bali, Lombok, Sumba, Sumbawa, Flores and Timor Kupang (except for Portuguese Timor) and the Moluccas (Ambon, Seram, North Maluku, Ternate, Tidore and Halmahera). Papua was not included.

Papua only came in on 24 August 1828, exactly on the birthday of King Willem II. General van Daldem, who led the military post in Lobo (Triton Bay) in Kaimana, proclaimed that it was precisely on the day of birth of the King of Holland that he entered the territory of Netherlands Nieuw-Guinea, lying from 129 degrees east longitude on the west to 141 degrees east longitude to the east, which then became a Dutch colony, Netherlands Nieuw-Guinea.

Thus, Nieuw-Guinea only came in as a second colony of the Netherlands in 1828. Many countries were unsympathetic to this proclamation, as Spain, through Ortis de Retes, had staked the Spanish flag in Sarmi, at the mouth of the Mamberamo river and proclaimed the land a 
Spanish possession by the name of Nova Guinea, meaning New Guinea, since its climate and people were truly like those of Guinea in West Africa, whose people were similarly black-skinned and kinky-haired. From that point on, the name New Guinea has been used, until now! 